\title{
The Risk-Taking Attitude of Student towards Mathematics through Inquiry-Based Open-Ended Learning
}

\author{
Yatha Yuni 1, Fiki Alghadari 2 \\ DOI: $10.35445 /$ alishlah.v13i1. 584
}

\section{Article Info}

Keywords: IBOE learning

Inquiry

Open-ended

Mathematics

Risk-taking attitude

Kata kunci:

Inkuiri

Matematika

Open-ended

Pembelajaran IBOE

Sikap risk-taking

\begin{abstract}
This research was to know students' achievement and improvement risk-taking attitudes in grade 7 at Madrasah Tsanawiyah in Bekasi City towards mathematics through Inquiry-Based Open-Ended (IBOE) learning. This research is quantitative research with the research design Non-equivalent Pre and Post-test Control-Group Design. There are 156 students as a sample. It was taken using the purposive sampling technique from two Madrasah Tsanawiyah (MTs). Seventy-seven students in the experimental class (IBOE) and 79 students in the control class (Direct Learning: DL). They were grouped according to previous mathematics abilities (level high, medium, and low). The instrument used was a questionnaire consisting of 17 valid statements adopted from the Domain-Specific Risk-Taking (DOSPERT) scale. The results of this research were reviewed based on early mathematical skills, achievement of the process of building a risk-taking attitude for MTs students. Students who received IBOE learning were no better than students who received DL. Meanwhile, based on the early mathematical skills, students who increase in building a risk-taking attitude received IBOE learning was better than students who received DL.
\end{abstract}

\begin{abstract}
Abstrak
Tujuan penelitian adalah untuk mengetahui pencapaian dan peningkatan sikap risk-taking siswa kelas 7 Madrasah Tsanawiyah di Kota Bekasi terhadap matematika melalui pembelajaran IBOE. Penelitian kuantitatif ini dengan rancangan penelitian Non-equivalent Pre and Post-test Control-Group Design. Sampel penelitian adalah 156 siswa Madrasah Tsanawiyah yang dibagi dalam dua kelompok, 77 siswa pada kelas eksperimen (IBOE) dan 79 siswa pada kelas kontrol (Direct Learning: DL) yang dikelompokkan berdasarkan kemampuan awal matematika (level tinggi, sedang, dan rendah). Instrumen yang digunakan adalah angket sebanyak 17 butir pernyataan yang sudah valid. Instrumen penelitian diadopsi dari the Domain Specific RiskTaking (DOSPERT) scale serta disesuaikan dengan kemampuan siswa kelas 7 MTs. Hasil penelitian ditinjau berdasarkan kemampuan awal matematika, pencapaian proses membangun sikap risk-taking peserta didik MTs. yang mendapat pembelajaran IBOE tidak lebih baik dibandingkan dengan yang mendapat DL. Sedangkan ditinjau berdasarkan kemampuan awal matematika, peningkatan membangun sikap risk-taking yang mendapat pembelajaran IBOE lebih baik dibandingkan dengan yang mendapat DL.
\end{abstract}

${ }^{1}$ STKIP Kusuma Negara, Jakarta, Indonesia

Email: yathayuni@stkipkusumanegara.ac.id

${ }^{2}$ STKIP Kusuma Negara, Jakarta, Indonesia

Email: fiki_alghadari@stkipkusumanegara.ac.id 


\section{INTRODUCTION}

The culture of the Indonesian people has more profit and loss than the risks that will be faced in life. News of crime on social media informs in accidents and even death, not affecting the victims, but also the perpetrators. It shows that the perpetrators only explain the benefits. In contrast to European culture, they prioritize minimal risk of maximum profit (Vasyakin et al., 2016). Therefore, it must be a concern for educators in Indonesia to consider the risks that will be accepted from an early age, starting from the learning process in the classroom. For example, cheating on exams, not doing assignments, or what is often done is skipping school. Minimizing the bad attitudes and behaviour of students is the goal of this research.

There are still many ordinary people who do not understand what risk-taking is. Besides being absorbed from foreign languages, risk-taking is rarely expressed in everyday life, especially in education. There is still little research on risk-taking in education research-more researching risktaking in economics, banking, or health. However, when viewed from the attitude that ultimately becomes a person's good or bad character, the world of education must start prioritizing students' risk-taking who are the next generation of the Indonesian nation.

Risk-taking is a person's attitude to make a decision. Risk-taking is the behavioural tendency of individuals attracted to objects with the potential to be painful or harmful but have positive opportunities (Friedman \& Schustack, 2018). Risk-taking can be explained as the desire to seize opportunities that may lead to significant losses or performance discrepancies (Kuratko \& Morris, 2018). People must have the ability to take risks because it is a part of people's character or personality (Yuni et al., 2018).

The character has been owned since someone was born because it is the nature of Allah. The existing characters must be built and awakened through thinking skills. The ability to think can be sharpened if used through learning in traditional schools. Learning that requires higher thinking skills is in exact subjects, including mathematics. The character will appear according to what is in someone's mind. If someone thinks about good things, then characters appear also good, but on the other hand, if someone thinks about bad things, then evil characters will appear (Rohana, 2015).

Taking decisions (risk-taking) is an essential attitude for individuals because it directly affects their social life (Bu et al., 2020; Friedl et al., 2020; Montinari \& Rancan, 2018). Of course, the impact of decision-making has been considered good or bad for the decision-maker and his social relationships. Taking decisions or risk-taking is influenced by the development of neuroscience (Hartley \& Somerville, 2015; Steinberg, 2017). The meant by neuroscience is human behaviour from the perspective of activities that occur in the brain. According to (Hartley \& Somerville, 2015) and (Steinberg, 2017) changes in the brain system that coincides with reproductive maturation that prompts risk-taking for adaptive evolution.

Likewise, when students solve mathematical problems, they must face choices that have risks. The risk they face is that their answers are correct, they get good grades, or their answers are wrong and get bad grades. This choice they have to face every time they solve math problems, so some of them become afraid and lazy to do math assignments from the teacher. It should be realized that so far, formal education only emphasizes the development of the cognitive domain. Developments in the affective domain are less noticed (Supardi, 2015). Risk-taking is part of the affective domain, which plays an essential role in making decisions when solving math problems (Quan, 2015; Turkmen \& Sertkahya, 2015). For example, when calculating the height of a prism, students must be creative in using the Pythagorean formula. However, when determining the sloping side, base side, and upright side requires a risky decision. Wrongly determine the answer gets a bad score. However, students must dare to take the risk rather than not answering. Such a risk-taking attitude must be practised.

Risk-taking or risk in making decisions must be built on each individual. Building courage in risk-taking must be trained continuously. It should be done early on when the child understands 
what is sick and what is not, for example, when he is learning to walk. He knew that when he first started walking, he would fall and that falling was painful. Nevertheless, the risk of falling and getting sick he had to take so he could walk. If he is afraid to do it again, then the process of being able to run will be hampered or take a long time (Tieskens et al., 2018). Risk-taking can positively or negatively impact (Brady, 2017; McLaren \& Arnold, 2016). According to the opinion of Tieskens et al. (2018) in which states that risk-taking behaviors are those that involve some potential for danger or harm while also providing an opportunity to obtain some form of reward. Furthermore, Brettel et al. (2015) and Tieskens et al. (2018) state that the same thing: Although risk-taking encompasses a broad range of behaviors that fall along both positive and negative dimensions. Taking risks have two possible behaviors, it can be positive or negative, beneficial or detrimental, or even dangerous.

In line with the previous opinion, the results of Steinberg's (2017) research describe the risktaking ability of the sample studied between the ages of 10-30 years described as a curve or curve. At the age of adolescence (puberty), around 7-29 years is at the stage of development (using the Connors Impulsivity Scale). In contrast, Ryan et al. (2013) stated a significant decline between 14-16 and 2022 (using Barratt's Impulsivity). Usually, at the age of adolescence to early adulthood, in making decisions or risk-taking abilities too quickly and boldly, somewhat ignoring the considerations or the impact of their decisions and tend to be careless because of the immaturity of emotions. However, with the development of emotions and hormones that mature in early adulthood, risk-taking is considered based on understanding, experience, and even previous observations. Therefore, the risktaking ability of students at junior high school age must be built so that they are more prepared earlier. With exercises to solve problems in mathematics, they are more trained, not careless, and ready to face the risks of their decisions. Whether the answer or solution made to the idea that appears will be correct or wrong, it is ready to be repeated with other ideas and ways-noting that this statement is in line with the behaviourism learning theory according to Edward Lee Thorndike, which contains four laws, namely: the law of readiness, the law of exercise, law of effect, and law of attitude (Pratama, 2019). If someone has readiness, then he will be careful in thinking and acting. If someone has considered his actions' good and bad risks, then his self-confidence will be high (Pratama, 2019).

Bandura's self-efficacy theory is formed by four sources of information: Successful experience (Alqurashi, 2016; Lyons \& Bandura, 2019). In human life, success in solving a problem will increase self-efficacy, otherwise, failure will reduce self-efficacy (especially when self-efficacy has not been established steadily in a person). To form self-efficacy, people must have experienced severe challenges to solve them with persistence and hard work. Self-efficacy is "one of the keys to student success in learning because, without self-efficacy, students will not be successful in interacting with their friends (Katz, 2015; Sha et al., 2016). Besides, without self-efficacy, students will hesitate in solving a problem. In the end, the student will not be optimal in solving the problem.

The learning was applied in this research to build students' risk-taking attitudes. It is a modification between Inquiry learning and the Open-ended approach in which the researcher calls IBOE. The novelty of IBOE learning in this study is the combination of inquiry and open-ended learning, which other researchers have not done in mathematics learning. So that five IBOE learning syntaxes are very supportive of building students' risk-taking attitudes. Zeev's opinion (Yuni et al., 2019) that teaching methods can activate students must discover learning. In this case, finding learning is an inquiry that is in the IBOE learning syntax. Finding solutions or answers to exciting and challenging open-ended questions tends to train students to make choices by considering and minimizing all risks that will be accepted. IBOE learning is scientific-based learning that is by the 2013 curriculum. It was related to learning orientation in the 21st century. A fundamental paradigm shift needs to be done to improve the learning environment in schools, which are primarily oriented to Teacher Center Learning to become Student Center Learning. Objects that become learning in the arrangement and refinement of K-13 emphasize natural, social, artistic, and cultural phenomena (Abidin, 2014). 
The inquiry comes from the word inquire (English), which means asking for information or an investigation (Wahyudin et al., 2010). The cognitive learning flow influences inquiry learning. According to this flow, learning is a mental process and a thought process by optimally utilizing each individual's potential. Applying inquiry learning begins with the assumption that humans have the urge to discover their knowledge since humans were born into the world. Curiosity about the natural conditions around him is human nature from birth into the world. Then since childhood, humans have always wanted to know something with their senses. This curiosity develops until humans mature. This curiosity must be adequately directed to generate positive benefits (Yuni et al., 2019).

According to Sanjaya (2019) and Sefalianti (2014), in general, the steps of Inquiry learning include: (1) Orientation; (2) Formulating problems; (3) Proposing a hypothesis; (4) Collecting data; (5) Testing the hypothesis; and (6) Formulating conclusions. Meanwhile, Inquiry learning proposed by Joyce \& Weil (in Putri et al., 2021; Yuni et al., 2019) includes five stages, stages, or steps of this learning which is better known as the learning syntax, namely: (1) Confrontation with the problem; (2) Data Gathering-Verification (3) Data Gathering-Experimentation; (4) Organizing, Formulating, and Explanation; (5) Analysis of the Inquiry process.

The Open-Ended approach was born nearly twenty years ago from research conducted by experts from Japan: Shigeru Shimada, Toshio Sawada, Yoshiko Yashimoto, and Kenichi Shibuya (Riansyah \& Suhar, 2014). The emergence of this approach was a reaction to school mathematics education at that time, whose class activity was called issei jugyow (frontal teaching); the teacher explains the new concept in front of the class to the students, then provide examples for solving some problems.

According to Becker \& Shimada (1997), the emergence of an Open-ended approach originated from the viewpoint of how to objectively evaluate students' abilities in higher-order thinking (HOT), especially in mathematics. The Open-ended approach provides an experience of the process of finding with the efforts of students themselves by combining experience, knowledge, and thinking skills (Ninomiya \& Pusri, 2015).

The steps (syntax) in inquiry and open-ended learning can be combined to improve students' risk-taking abilities. The second syntax of learning modification, the researcher calls IBOE learning, is depicted in Figure 2.

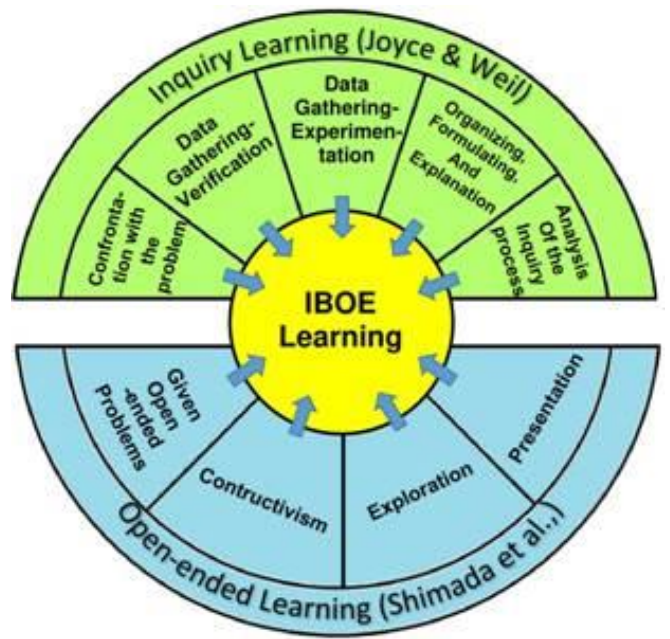

\section{Figure 1. IBOE Learning modification Syntax.}

Several previous researchers who have researched risk-taking in learning mathematics researched things that were different from this research. Supardi (2015) examines the role of creative thinking in learning mathematics. One indicator of creative thinking is a risk-taking attitude which is part of divergent thinking. Supardi (2015) defines a risk-taking attitude as the ability to try something full of risk. Supardi's research wanted to see the effect of 9 th-grade junior high school students' creative thinking on mathematics learning achievement without implementing teaching 
methods. Another researcher, Rokhaeni (2014), researched risk-taking, which is part of the creative thinking indicator. Hasanah et al. (2013) researched the thinking process of male and female junior high school students with an extrovert and introvert personality type in solving math problems using Polya steps. Their researchers did not focus on researching risk-taking attitudes. so indicators of risk-taking have not been seen.

Based on previous research that has not focused on researching risk-taking attitudes, even though this attitude is vital to be trained from the start, this research focuses on several problems. The objectives and problem formulations in this research are: (1) How do students achieve risktaking attitudes towards mathematics based on the KAM level through IBOE learning? (2) How to increase students' risk-taking attitude towards mathematics through IBOE learning? (3) Are there differences in the increase in students' risk-taking attitudes towards mathematics between IBOE learning and direct learning?

\section{METHODS}

The Nonequivalent Pre-test and Post-test Control-Group Design (Creswell \& Creswell, 2017; Sugiyono, 2012). The population of this research is MTs students in East Bekasi. The purposive sampling technique selected the sample. They are students in 7.1 grade from MTs. A, and 7.2 grade from MTs B in the odd semester of the 2019/2020 school year. These two schools have almost the same criteria. Purposive sampling is a sampling technique with specific considerations (Sugiyono, 2012). The conditions that must be met in determining a sample with a specific purpose include: sampling must be based on certain characteristics, traits, or characteristics that are the main characteristics of the population (Suharsimi, 2016). Then the sample is divided into experimental and control groups. Each group is further divided based on Initial Mathematics Ability or KAM (high, medium, and low), aiming to determine the effect of IBOE learning in increasing risk-taking attitudes more effectively at high, medium, or low. More details on sample selection are presented in the following Table 1.

Table 1. Sample of Data

\begin{tabular}{|c|c|c|c|c|}
\hline \multirow{2}{*}{ MTs. } & \multicolumn{2}{|r|}{ Eksperimen Group } & \multicolumn{2}{|r|}{ Kontrol Group } \\
\hline & Class & Level KAM (students) & Class & Level KAM (students) \\
\hline A & 7.1 & $\begin{array}{l}\text { High }=10 \\
\text { Medium }=18 \\
\text { Low }=10\end{array}$ & 7.5 & $\begin{array}{l}\text { High }=9 \\
\text { Mediun }=18 \\
\text { Low }=12\end{array}$ \\
\hline B & 7.2 & $\begin{array}{l}\text { High }=10 \\
\text { Medium }=18 \\
\text { Low }=11\end{array}$ & $7 \cdot 3$ & $\begin{array}{l}\text { High }=9 \\
\text { Medium }=19 \\
\text { Low }=12\end{array}$ \\
\hline & tal & 77 & & 79 \\
\hline
\end{tabular}

Determine high, medium, and low KAM in each class of the research sample. According to Arikunto (2016), based on the position of students, standard deviation. It was done by grouping the top 3 ranks. The names were the upper (high), medium, and low groups with boundaries, as shown in Table 2.

Table 2. KAM Category

\begin{tabular}{cc}
\hline Criteria KAM (x) & Category \\
\hline$x \geq \mu+S D$ & High \\
$\mu-S D \leq x<\mu+S D$ & Medium \\
$x<\mu-S D$ & Low \\
\hline \hline
\end{tabular}

The KAM criteria in this research, used $1 / 2 \mathrm{SD}$, with the aim of one class, can be described as a normal curve. Calculations using $1 / 2$ SD do not violate the provisions, because according to Arikunto (2016), determining the moderate group can be done between -1SD and $+1 \mathrm{SD}$. The total number of samples in this research was 156 students. 
This research instrument uses 20 items questionnaire adopted from Domain-Specific RiskTaking (DOSPERT) scale developed by Weber, Blais, and Betz (2002). Initially, 20 questionnaires were made, and the instrument grille as shown in Table 3.

Table 3. Aspect and Indicator of Risk-Taking

\begin{tabular}{clcc}
\hline \multirow{2}{*}{ Aspect Risk-Taking } & \multicolumn{1}{c}{ Indicator } & \multicolumn{2}{c}{ item } \\
\cline { 2 - 4 } & & + & - \\
\hline Readiness & Be careful in actions & $1,2,4$ & 3,11 \\
\cline { 2 - 4 } & It has calm in thinking & $5,12,13,16$ & 6 \\
\hline \multirow{2}{*}{ Self-efficacy } & Firm in making a decision & $7,8,18$ & 14,17 \\
\cline { 2 - 4 } & Steady in action & $15,19,20$ & 9,10 \\
\hline & Total & 13 & 7 \\
\hline
\end{tabular}

The indicators of risk-taking are drawn in figure 1 below:

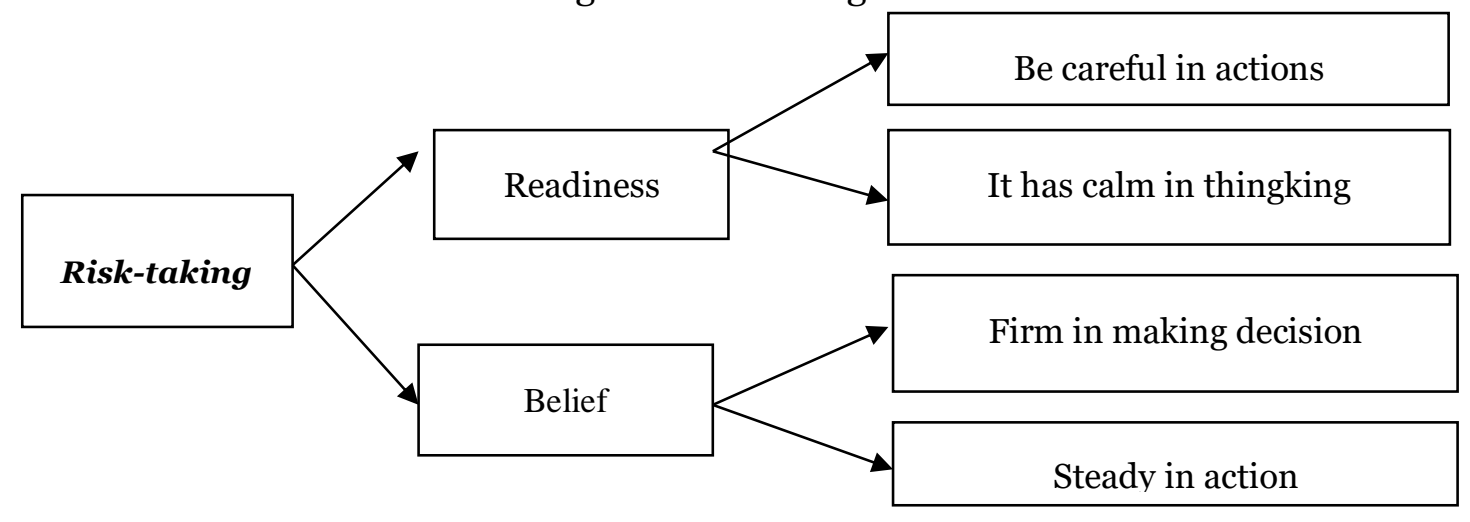

Figure 2. Indicator Risk-Taking

\section{FINDINGS AND DISCUSSION}

IBOE learning was applied in this research. The strength is the Student's Worksheet (SW) prepared by the researcher to guide students to find their own mathematical problem-solving. The following is the atmosphere of the students when solving math problems on the SW. In general, the implementation of IBOE learning went quite well and was acceptable to students. The activities of students and teachers (in this case by researchers) during the learning process can be seen through direct observation. The learning was carried out eight times outside the pre-test and post-test. Each meeting takes place with 2 hours of lessons or about 80 minutes and 3 hours of lessons or about 120 minutes.

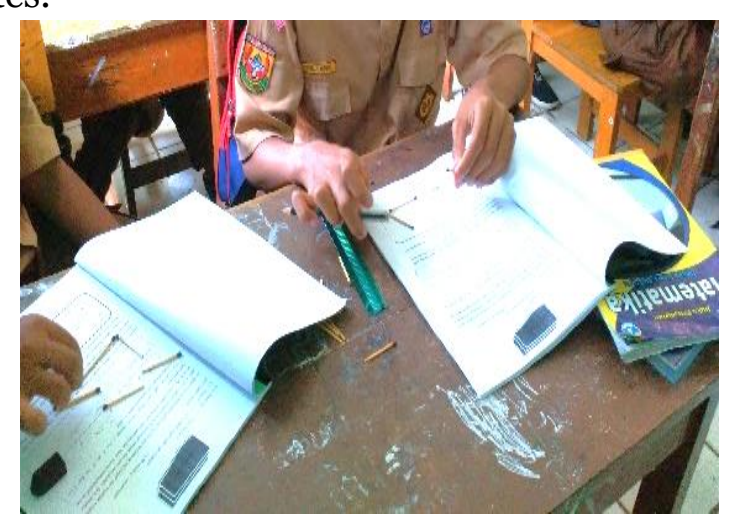

(a)

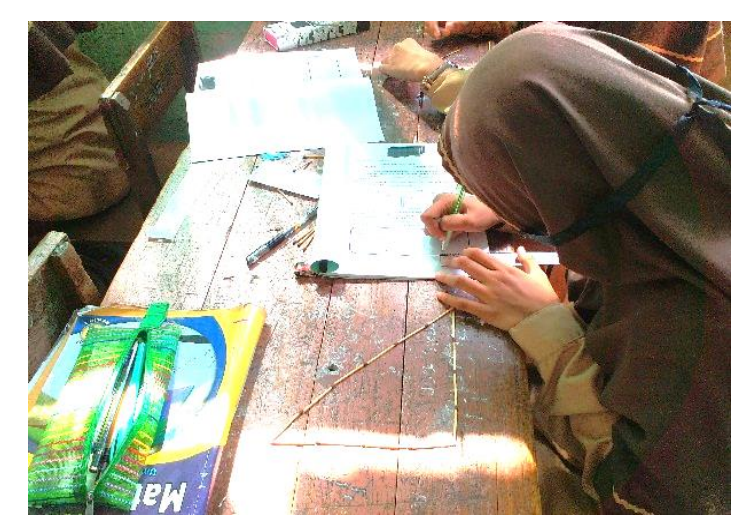

(b)

Figure 3. (a) dan (b) Situation when students implementation IBOE Learning by SW guide

The learning atmosphere looks focused, the SW guide directs students to find their own mathematical problem-solving. Students were active. They experiment with helped by the existing media (matches or sticks). The IBOE learning steps train them to try, decide for themselves in what way to solve it. The attitude of making decisions is, of course, given directions by the teacher all the 
consequences. A learning process like this is what builds students' risk-taking attitudes. IBOE learning has characteristics based on a scientific approach to the process with 5 stages of learning (syntax): 1) problem presentation, 2) data collection, 3) experimentation or trial and error, 4) data organization and formulation of conclusions, and 5) analysis of the discovery process. . The IBOE learning syntax that builds students' risk-taking attitudes is when they find solutions to mathematical problems independently. At this stage, students are faced with choices with the risk of correct answers or wrong answers. For example, given the problem in Figure 4: Is the area of triangle $\mathrm{ADC}$ smaller than $\mathrm{ABC}$ ? The information is given in this problem, the symbol $t$, shows the triangle's height, and you must find the following information, where is the base of the triangle. The next step is to construct or construct that the area of the triangle $=$ the base height. Then, the base of the two triangles is equal, namely AC., and finally, it was found that Area $\mathrm{ADC}=\mathrm{Area} \mathrm{ABC}$.

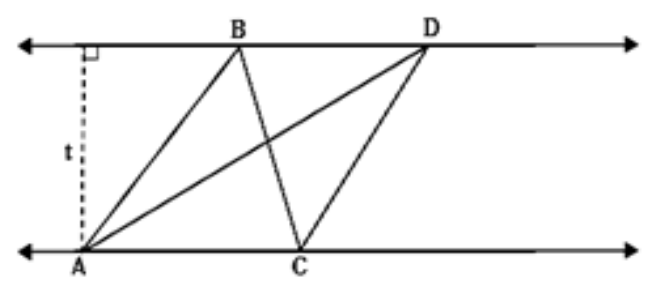

Figure 4. Examples of mathematical problems related Gathering-Verification with constructivism.

When we focus on the two triangles ( $\mathrm{ABC}$ and $\mathrm{ADC}$ ), almost all students state that their area is different. It means that at first thought, the risk of their answer is wrong. Then the teacher guides by reminding the concept that the area of a triangle is the base $\mathrm{x}$-height. Students are asked to look back at the pictures of the two triangles and find the base and height. Teacher guidance in implementing IBOE learning steps for 7 th graders is significant. SW as a guide for students to find their mathematical problem-solving.

After obtaining the data by distributing questionnaires, 17 valid and reliable questions were tested on 38 students of 7.4 MTS. Furthermore, a valid questionnaire was given to the experimental class (IBOE) and control class (direct learning) to obtain research data. The scoring technique uses a score range from 1-4 (continuum data). Therefore, it is not too extreme in giving an assessment compared to using a score of $\mathrm{o}$ and 1 (dichotomy). The valid questionnaires were then given to 156 students' MTs. Data in the form of scores were then converted using the Method of Successive Interval (MSI) program to convert ordinal data into interval data. The initial score results compared to the score after conversion showed a slight improvement, but it did not change the mean score. It means that the first score with the score after conversion is not significantly different.

Research data to measure achievement and improvement in building risk-taking attitudes are in Table 4.

Table 4. Achievement Data and Improvement Risk-Taking Attitude

\begin{tabular}{|c|c|c|c|c|c|c|c|}
\hline \multirow{2}{*}{ KAM Level } & \multirow{2}{*}{ Statistic } & \multicolumn{3}{|c|}{ IBOE Learning } & \multicolumn{3}{|c|}{ Conventional Learning } \\
\hline & & Pre-test & Postest & N_Gain & Pre-test & Postest & $N \_$Gain \\
\hline \multirow{3}{*}{ High } & $N$ & & 20 & & & 18 & \\
\hline & $\bar{x}$ & 57,034 & 63,222 & 0,259 & 63,023 & 62,492 & $-0,020$ \\
\hline & $s d$ & 6,725 & 5,652 & 0,112 & 6,118 & 6,980 & 0,139 \\
\hline \multirow{3}{*}{ Medium } & $N$ & & 36 & & & 37 & \\
\hline & $\bar{x}$ & 47,820 & 49,867 & 0,060 & 51,709 & 51,567 & $-0,005$ \\
\hline & $s d$ & 2,812 & 3,423 & 0,068 & 3,217 & 3,249 & 0,005 \\
\hline \multirow{3}{*}{ Low } & $N$ & & 21 & & & 24 & \\
\hline & $\bar{x}$ & 41,026 & 45,052 & 0,098 & 48,869 & 49,312 & 0,007 \\
\hline & $s d$ & 5,092 & 4,862 & 0,065 & 4,994 & 4,215 & 0,082 \\
\hline Totally & $N$ & & 77 & & & 79 & \\
\hline
\end{tabular}




\begin{tabular}{cccccccc}
\hline \hline \multirow{2}{*}{ KAM Level } & \multirow{2}{*}{ Statistic } & \multicolumn{3}{c}{ IBOE Learning } & \multicolumn{3}{c}{ Conventional Learning } \\
\cline { 2 - 8 } & & Pre-test & Postest & $N \_$Gain & Pre-test & Postest & $N \_$Gain \\
\cline { 2 - 8 } & $\bar{x}$ & 48,360 & 52,023 & 0,122 & 53,424 & 53,371 & $-0,0049$ \\
$s d$ & 7,521 & 8,261 & 0,115 & 7,024 & 6,822 & 0,087 \\
\hline
\end{tabular}

The N-Gain column is the data resulting from an increase in building a risk-taking attitude. It is described in the following diagram.

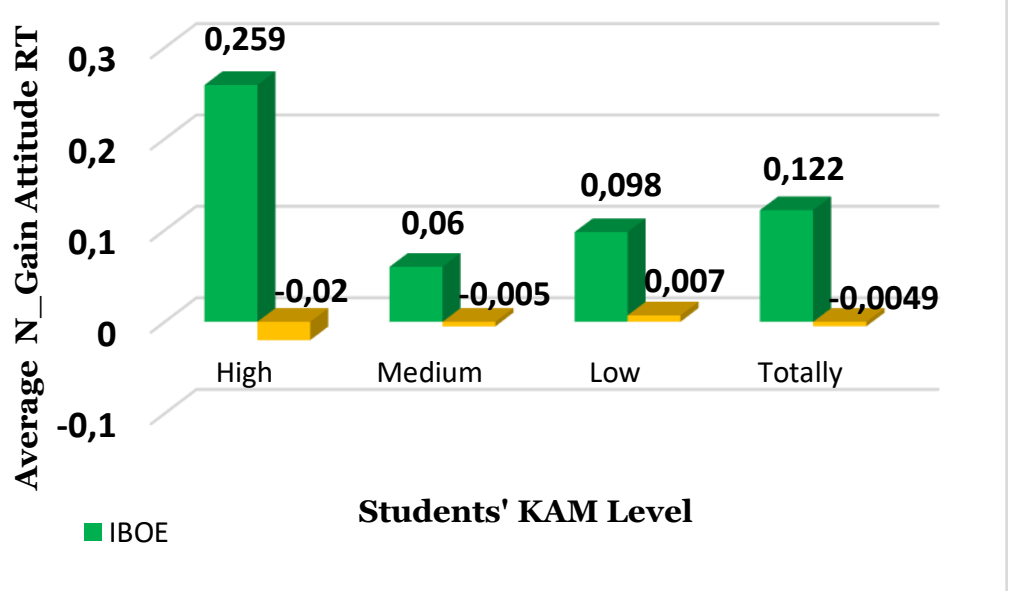

\section{Figure 5. Chart Achievement and Improvement Risk-Taking Attitude}

Based on the data were obtained from pre-test to post-test as presented in Table 4, in the IBOE learning group, the order of the highest N_Gain is at high KAM (0.259), followed by overall KAM (0.122), low KAM (0.098), and moderate KAM (0.060). While in the direct learning group, the average N_Gain value of each group is $\leq 0$. Considering the N_Gain value between the two learnings, the overall increase in risk-taking attitudes and based on KAM level is better for the IBOE group than the DL group.

At a high KAM level, medium and low KAM, the increase of risk-taking attitudes is higher in the IBOE learning than in the direct learning group. The difference in the KAM level increases, the requirements test is carried out; first, it is the normality and homogeneity test.

Table 5. Recapitulation Normality-test based on KAM Level

\begin{tabular}{cccccc}
\hline KAM Level & Learning & N & K-S & Asymp. Sig. (2-tailed) & Information \\
\hline \multirow{2}{*}{ High } & IBOE & 20 & 0,927 & 0,357 & Normal \\
& Direct Learning & 18 & 1,054 & 0,216 & Normal \\
\hline \multirow{2}{*}{ Medium } & IBOE & 36 & 0,705 & 0,704 & Normal \\
& Direct Learning & 37 & 0,990 & 0,281 & Normal \\
\hline \multirow{2}{*}{ Low } & IBOE & 21 & 0,655 & 0,784 & Normal \\
& Direct Learning & 24 & 0,985 & 0,286 & Normal \\
\hline \hline
\end{tabular}

Data for all levels of KAM in the IBOE group and direct learning are normally distributed because of the Asymp value. Sig. (2-tailed) $>\alpha=0.05$. Because it was the normal requirements, it can be continued with the homogeneity test and difference test ( $t$-test) using the Levene test.

Table 6. Recapitulation Levene test dan $t$-test based on KAM Level

\begin{tabular}{lcccccc}
\hline \multirow{2}{*}{ KAM Level } & \multicolumn{3}{c}{ Levene-test } & \multicolumn{3}{c}{$t$-test for Equality of Means } \\
\cline { 2 - 7 } & $N$ & $F$ & Sig. & $t$ & $d f$ & Sig. (2-tailed) \\
\hline High & 38 & 0,685 & 0,413 & 6,82 & 36 & 0,000 \\
Medium & 73 & 3,156 & 0,080 & 4,64 & 71 & o, ooo \\
Low & 45 & 3,386 & 0,073 & $-2,27$ & 43 & o,o28 \\
\hline \hline
\end{tabular}


Based on Table 6, the Levene test has obtained the Sig. $>\alpha=0.05$, then all KAM level data are homogeneous. Because the data are normal and homogeneous, the difference test is done by using the $t$-test. For the $t$-test of all KAM levels, Sig. (2-tailed) $<\alpha=0.05$, so there are differences in students' risk-taking attitudes using IBOE learning with direct learning. The findings of this research are in line with the results of Steinberg's research describing the risk-taking ability of the samples studied between the ages of 10 and 30 years to be described as arch or curves. In adolescence (puberty), around 7-29 years is developmental (using the Connors Impulsive Scale).

On the other hand, Leshem \& Glicksohn (2007) stated a significant decrease from age 14-16 to 20-22 (using Eysenk \& Barratt Impulsivity). Usually, at the age before adolescence to early adulthood, making decisions or risk-taking abilities too fast and bold, somewhat ignoring the considerations or the impact of his decisions. It tended to be careless because of immature emotions. However, as emotional development and hormones mature in early adulthood, the ability to take risk-taking is more of a consideration. Judgments made based on understanding, experience, and even previous observations are an attitude of responsibility. Therefore, the risk-taking ability of students at junior high school must be built with practice solving problems in mathematics to increase the sense of responsibility for the assignment was given by the teacher, regardless of whether the answer or solution is correct or wrong. If it is wrong, then it is ready to be repeated with other ideas and ways. This further enhances the attitude of students' responsibility on their assignments.

Based on the results of the research and tests carried out, especially the difference test in Table 6, then:

(a) At a high KAM level, the $t$-test $=6.82$ with degrees of freedom $(d f)=36$ and Sig. (2-tailed) $=$ o.ooo. The proposed hypothesis test is a one-party test, then the Sig. (2-tailed) must be divided by two (0.000: 2 ) $=0.000$. Sig value. $(2$-tailed) $=0.000<\alpha=0.05$, this means that $H 0: \mu 1 \leq \mu 2$ is rejected and $H_{1}: \mu 1>\mu 2$ is accepted. It can be concluded that the hypothesis states, "Increasing the process of building risk-taking attitudes of student' MTs who get better IBOE learning than students who get regular learning based on high KAM levels".

(b) At the medium KAM level, the $t$-test $=4.64$ with degrees of freedom $(d f)=71$ and Sig. (2-tailed) $=0.000$. Because the hypothesis test is a one-party test, the Sig. (2-tailed) must be divided by two (0.000: 2) $=0.000$. Sig value. (2-tailed) $=0.000<\alpha=0.05$, this means that Ho: $\mu 1 \leq \mu 2$ is rejected and $H_{1}: \mu 1>\mu 2$ is accepted. It can be concluded that the hypothetical statement "Improved the process of building risk-taking attitudes of MTs students who get better IBOE learning than those who receive regular learning based on moderate KAM level".

(c) At low KAM level, the $t$-test $=-2.27$ is obtained with degrees of freedom $(d f)=43$ and Sig. (2tailed) $=0.028$. Because the hypothesis test is a one-party test, the Sig. (2-tailed) must be divided by two (0.028: 2$)=0.014$. Sig value. $(2$-tailed) $=0.014<\alpha=0.05$, this means that $H 0: \mu 1 \leq \mu 2$ is rejected and $H_{1}: \mu 1>\mu 2$ is accepted. It can be concluded that the hypothesis which states "The increase in the mathematical reasoning abilities of students's who get IBOE learning is better than students who get regular learning based on low KAM levels."

\section{CONCLUSION}

The conclusions of this study are: (1) The achievement of a risk-taking attitude can be seen from the post-test results. Overall, the post-test results of the IBOE study group were not better than the direct study group. However, the increase in risk-taking attitudes at the KAM level (high, medium, low) who received IBOE learning was better than direct learning. (2) The improvement of forming a risk-taking attitude in MTs students can be seen from the normal gain value. Students who receive IBOE learning are better than students who receive direct learning in overall or based on KAM levels (high, medium, and low). (3) There are differences in students' overall risk-taking attitudes, and levels of KAM taught with IBOE learning compared to direct learning.

The limitation of this study is finding sources from previous research because the risk-taking variables studied are minimal, whereas building a student's risk-taking attitude from junior high 
school age through habituation is very important. Life in society is constantly faced with risky choices. However, if trained from an early age, the risks received can be minimized. They built a risktaking attitude for students to be more trained through habituation and practice in solving math problems. Other researchers still have a great opportunity to conduct further research to give birth to the next generation of Indonesians in facing increasingly complex life challenges by minimizing their risks.

\section{REFERENCES}

Abidin, Y. (2014). Desain sistem pembelajaran dalam konteks kurikulum 2013. Bandung: Refika Aditama.

Alqurashi, E. (2016). Self-Efficacy In Online Learning Environments: A Literature Review. Contemporary Issues in Education Research (CIER), 9(1), 45-52. https://doi.org/10.19030/cier.v9i1.9549

Arikunto, S. (2016). Dasar-dasar evaluasi pendidikan. Jakarta: Bumi Aksara.

Becker, J. P., \& Shimada, S. (1997). The Open-Ended Approach: A New Proposal for Teaching Mathematics. Virginia: NTCM.

Brady, D. (2017). Assessment and therapeutic management of risk. In A. Clifton, S. Hemingway, A. Felton, \& G. Stacey (Eds.), Fundamentals of Mental Health Nursing: An Essential Guide for Nursing and Healthcare Students (p. 84). Oxford, UK: John Wiley \& Sons, Ltd.

Brettel, M., Chomik, C., \& Flatten, T. C. (2015). How Organizational Culture Influences Innovativeness, Proactiveness, and Risk-Taking: Fostering Entrepreneurial Orientation in SMEs. Journal of Small Business Management, 53(4), 868-885. https://doi.org/10.1111/jsbm.12108

Bu, D., Hanspal, T., Liao, Y., \& Liu, Y. (2020). Risk taking during a global crisis: Evidence from wuhan. In C. Wyplosz (Ed.), Covid Economics: Vetted and Real-Time Papers (Vol. 5, pp. 106-146). CEPR Press.

Creswell, J. W., \& Creswell, J. D. (2017). Research design: Qualitative, quantitative, and mixed methods approaches. USA: Sage publications.

Friedl, A., Pondorfer, A., \& Schmidt, U. (2020). Gender differences in social risk taking. Journal of Economic Psychology, 77, 102182. https://doi.org/10.1016/j.joep.2019.06.005

Friedman, H. S., \& Schustack, M. W. (2018). Personality: Classic theories and modern research. Boston, MA: Allyn and Bacon.

Hartley, C. A., \& Somerville, L. H. (2015). The neuroscience of adolescent decision-making. Current Opinion in Behavioral Sciences, 5, 108-115. https://doi.org/10.1016/j.cobeha.2015.09.004

Hasanah, N., Mardiyana, M., \& Sutrima, S. (2013). Analisis proses berpikir siswa dalam memecahkan masalah matematika ditinjau dari tipe kepribadian extrovert-introvert dan gender. Jurnal Pembelajaran Matematika, 1(4), 422-434.

Katz, J. (2015). Implementing the Three Block Model of Universal Design for Learning: effects on teachers' self-efficacy, stress, and job satisfaction in inclusive classrooms K-12. International $\begin{array}{llll}\text { Journal of Inclusive } & \text { Education, } & 19(1), & 1-20 .\end{array}$ https://doi.org/10.1080/13603116.2014.881569

Kuratko, D. F., \& Morris, M. H. (2018). Corporate Entrepreneurship: A Critical Challenge for Educators and Researchers. Entrepreneurship Education and Pedagogy, 1(1), 42-60. https://doi.org/10.1177/2515127417737291

Leshem, R., \& Glicksohn, J. (2007). The construct of impulsivity revisited. Personality and Individual Differences, 43(4), 681-691. https://doi.org/10.1016/j.paid.2007.01.015

Lyons, P., \& Bandura, R. (2019). Self-efficacy: core of employee success. Development and Learning in Organizations: An International Journal, 33(3), 9-12. https://doi.org/10.1108/DLO-042018-0045

McLaren, M.-R., \& Arnold, J. (2016). Transforming Pedagogies: Encouraging Pre-service Teachers to Engage the Power of the Arts in their Approach to Teaching and Learning. Australian Journal of Teacher Education, 41(5), 21-35. https://doi.org/10.14221/ajte.2016v41n5.2

Montinari, N., \& Rancan, M. (2018). Risk taking on behalf of others: The role of social distance. Journal of Risk and Uncertainty, 57(1), 81-109. https://doi.org/10.1007/s11166-018-92862

Ninomiya, N., \& Pusri, P. (2015). The study of open-ended approach in mathematics teaching using 
jigsaw method. Bulletin of Saitama University Faculty of Education, 64, 11-22. https://doi.org/10.24561/oo017737

Pratama, Y. A. (2019). Relevansi Teori Belajar Behaviorisme Terhadap Pendidikan Agama Islam. Jurnal Pendidikan Agama Islam Al-Thariqah, 4(1), 38-49. https://doi.org/10.25299/althariqah.2019.vol4(1).2718

Putri, L. A., Permanasari, A., Winarno, N., \& Ahmad, N. J. (2021). Enhancing Students' Scientific Literacy Using Virtual Lab Activity with Inquiry-Based Learning. Journal of Science Learning, 4(2), 173-184. https://doi.org/10.17509/jsl.v4i2.27561

Quan, L. (2015). Perceptions of Leadership Competencies and the Acquisition of Them by CEOs in Vietnamese Small Enterprises. Asian Social Science, 11(4), 17. https://doi.org/10.5539/ass.v11n4p17

Riansyah, F., \& Suhar, S. (2014). Peningkatan Kemampuan Berpikir Kreatif Matematik Siswa Kelas XI IPA SMA Negeri 5 Kendari dengan Menggunakan Pendekatan Pembelajaran Open-Ended. Jurnal Penelitian Pendidikan Matematika, 2(1), 43-55.

Rohana, R. (2015). Meningkatkan karakter mahasiswa calon guru melalui pembelajaran reflektif. Symmetry: Jurnal Ilmiah Pendidikan Matematika FKIP UNPAS, 4(1), 571-582.

Rokhaeni, A. (2014). Pendekatan M-APOS untuk meningkatkan kemampuan berpikir kritis dan kreatif matematis serta habit of taking responsible risk matematika siswa. Univeritas Pendidikan Indonesia.

Ryan, K. K., MacKillop, J., \& Carpenter, M. J. (2013). The relationship between impulsivity, risktaking propensity and nicotine dependence among older adolescent smokers. Addictive Behaviors, 38(1), 1431-1434. https://doi.org/10.1016/j.addbeh.2012.08.013

Sanjaya, W. (2019). Strategi pembelajaran berorientasi standar proses pendidikan. Jakarta: Kencana Prenada Media.

Sefalianti, B. (2014). Penerapan pendekatan ekspositori terhadap kemampuan komunikasi dan disposisi matematis siswa. Jurnal Pendidikan Dan Keguruan (e-Journal), 1(2).

Sha, L., Schunn, C., Bathgate, M., \& Ben-Eliyahu, A. (2016). Families support their children's success in science learning by influencing interest and self-efficacy. Journal of Research in Science Teaching, 53(3), 450-472. https://doi.org/10.1002/tea.21251

Steinberg, L. (2017). A social neuroscience perspective on adolescent risk-taking. Developmental Review, 28(1), 78-106. https://doi.org/10.1016/j.dr.2007.08.002

Sugiyono, S. (2012). Metode Penelitian Pendidikan. Bandung: Alfabeta.

Suharsimi, A. (2016). Metodologi Penelitian. Yogyakarta: Bina Aksara.

Supardi, U. S. (2015). Peran berpikir kreatif dalam proses pembelajaran matematika. Formatif: Jurnal Ilmiah Pendidikan MIPA, 248-262. https://doi.org/10.30998/formatif.v2i3.107

Tieskens, J. M., Buil, J. M., Koot, S., Krabbendam, L., \& van Lier, P. A. C. (2018). Elementary school children's associations of antisocial behaviour with risk-taking across 7-11 years. Journal of Child Psychology and Psychiatry, 59(10), 1052-1060. https://doi.org/10.1111/jcpp.12943

Turkmen, H., \& Sertkahya, M. (2015). Creative thinking skills analyzes of vocational high school students. Journal of Educational and Instructional Studies in the World, 5(10), 74-84.

Vasyakin, B. S., Ivleva, M. I., Pozharskaya, Y. L., \& Shcherbakova, O. I. (2016). A Study of the Organizational Culture at a Higher Education Institution [Case Study: Plekhanov Russian University of Economics (PRUE)]. International Journal of Environmental and Science Education, 11(10), 11515-11528.

Wahyudin, W., Sutikno, S., \& Isa, A. (2010). Keefektifan pembelajaran berbantuan multimedia menggunakan metode inkuiri terbimbing untuk meningkatkan minat dan pemahaman siswa. Jurnal Pendidikan Fisika Indonesia, 6(1), 58-62.

Yuni, Y., Alghadari, F., \& Wulandari, A. (2019). Gender reviewed mathematical intuition at 7 th grade students through open-ended based-inquiry learning. Journal of Physics: Conference Series, 1315(1), 012080. https://doi.org/10.1088/1742-6596/1315/1/012080

Yuni, Y., Darhim, \& Turmudi. (2018). The attitude of risk taking Islamic junior high school ( MTs ) students in learning mathematics. Journal of Physics: Conference Series, 1013(1), 012113. https://doi.org/10.1088/1742-6596/1013/1/012113 